\title{
RESEARCH EXCHANGE AT ONE OF THE TOP AMERICAN INSTITUTIONS - UNIVERSITY OF MICHIGAN
}

Uroš Marušič, Ph.D. employed at the Science and Research Centre Koper and Alma Mater Europaea-European Center, Maribor, visited the Functional Neuroimaging, Cognition and Mobility Laboratory at one of the most prestigious and biggest higher education institutions in the USA, the University of Michigan (http://pdresearch.rad.med. umich.edu/). The exchange was carried out within the framework of the operation "Mobility of Higher Education Teachers AMEU-ECM 2018-2021" funded by the Ministry of Education, Science and Sport, between September 2018 and February 2019. According to Shanghai ranking score, the University of Michigan ranks the $20^{\text {th }}$ among all universities in the world (http://www.shanghairanking.com/ARWU2019.html).

Marušič was actively involved in the laboratory work of Nicolaas Bohnen, MD, Ph.D., and Martin Muller, Ph.D., who are proactive in the research area of postural instability and mobility difficulties of Parkinson's disease patients. Their studies successfully combine behavior with neuroimaging data, especially with positron emission tomography (PET) and cholinergic receptors. In the framework of this exchange, researchers have recently published the common research manuscript: Müller, M. L., Marusic, U., van Emde Boas, M., Weiss, D., \& Bohnen, N. I. (2019). Treatment options for postural instability and gait difficulties in Parkinson's disease. Expert review of neurotherapeutics, 19(12), 1229-1251. https://doi.org/10.1080/14737175.2019.165 6067.

During the exchange at the University of Michigan, Marušič also dived into the field of neuroergonomics, where he successfully completed the study with elderly patients with type 2 diabetes.

Parallel with his intensive research work, Marušič delivered numerous lectures at the University of Michigan Medical School for undergraduate, doctoral and postdoctoral students.

The exchange in the USA has brought many positive effects for both institutions. Namely, in the period between April and October 2019, a joint neuroergonomic study KOGIS (Cognitive and Motor Benefits of Standing) was conducted at the Mediterranean Health Centre (ZRS Koper), where researchers examined new possibilities for ergonomic arrangement of office workers and consequently the effects of newly developed ergonomic worktables on musculoskeletal discomfort, brain electrocortical activity, cognitive ability and work efficiency. 


\section{IZMENJAVA NA ENI VODILNIH AMERIŠKIH UNIVERZ - UNIVERZA V MICHIGAN-U}

Raziskovalec Znanstveno-raziskovalnega središča Koper in Alma Mater Europaea-e, se je v sklopu razpisa »Mobilnost slovenskih visokošolskih učiteljev 2018-2021 « Ministrstva za izobraževanje, znanost in šport, med septembrom 2018 in februarjem 2019 mudil na eni največjih in najprestižnejših ameriških visokošolskih institucij, Univerzi v Michigan-u (Ann Arbor, Michigan, ZDA), natančneje v Laboratoriju za funkcionalno možgansko slikanje, kognicijo in mobilnost (http://pdresearch.rad.med.umich.edu/). $\mathrm{Na}$ Shanghaiski lestvici najboljših 500 univerz na svetu, je Univerza v Michiganu uvrščena na prestižno 20. mesto (http://www.shanghairanking.com/ARWU2019.html).

Dr. Marušič je raziskoval v laboratoriju prof. dr. Nicolaas-a Bohnen-a in dr. Martina Müller-ja, ki delujeta predvsem na področjih posturalne nestabilnosti in težav mobilnosti pri Parkinsonovih bolnikih ter v svojih raziskavah uspešno primerjata vedenjske vzorce $z$ rezultati možganskih slik, predvsem pozitronske emisijske tomografije (PET) in holinergičnih receptorjev. V sklopu izmenjave so raziskovalci objavili skupni pregledni članek: Müller, M. L., Marusic, U., van Emde Boas, M., Weiss, D., \& Bohnen, N. I. (2019). Treatment options for postural instability and gait difficulties in Parkinson's disease. Expert review of neurotherapeutics, 19(12), 1229-1251. https://doi.org/1 0.1080/14737175.2019.1656067.

Dr. Marušič se je med izmenjavo na Univerzi v Michiganu poglobil tudi v področje nevroergonomije, kjer je uspešno zaključil študijo na pacientih s sladkorno boleznijo tipa 2.

Vzporedno z intenzivnim raziskovalnim delom je dr. Marušič izvedel številna predavanja za dodiplomske, doktorske in podoktorske študente v sklopu Medicinske fakultete Univerze v Michiganu.

Izmenjava v ZDA je prinesla številne pozitivne učinke za obe inštituciji. Tako je že v obdobju od aprila do oktobra 2019 potekala skupna nevroergonomska raziskava KOGIS (Kognitivne in gibalne prednosti stoječega delovnega mesta) v Mediteranskem centru zdravja ZRS Koper, v okviru katere smo preverjali nove možnosti ergonomske ureditve delovnih mest pisarniških delavcev in posledične učinke novo razvite ergonomske delovne mize na skeletno-mišično neugodje, možgansko elektrokortikalno aktivnost, kognitivne sposobnosti in delovno učinkovitost.

Uroš Marušič 